\title{
Novel practice to produce safe and healthy dry fish using irradiated chitosan coating
}

\author{
${ }^{1,2}$ Rahman, M.L., ${ }^{1,7}$ Barua, R., ${ }^{1,5}$ Jubayer, A.A., ${ }^{1,2,3}$ Islam, J.M.M., ${ }^{4}$ Kamal, A.H.M., \\ ${ }^{1}$ Ali, M., ${ }^{1}$ Hossain, M.S., ${ }^{1,2}$ Rahaman, M.S., ${ }^{6}$ Rahaman, M.S., ${ }^{4}$ Hossain, M.A., ${ }^{4}$ Huque, R. \\ and ${ }^{1,2, *}$ Khan, M.A. \\ ${ }^{1}$ Institute of Radiation and Polymer Technology, Atomic Energy Research Establishment, Gonokbari, Savar, \\ Dhaka, Bangladesh \\ ${ }^{2}$ Sonali Bag Project, Bangladesh Jute Mills Corporation, Ministry of Textiles and Jute, Bangladesh \\ ${ }^{3}$ Monash University Malaysia, Jalan Lagoon Selatan, Bandar Sunway, 47500 Subang Jaya, Selangor, \\ Malaysia \\ ${ }^{4}$ Institute of Food and Radiation Biology, Atomic Energy Research Establishment, Gonokbari, Savar, \\ Dhaka, Bangladesh \\ ${ }^{5}$ Department of Biotechnology and Genetic Engineering, Bangabandhu Sheikh Mujibur Rahman Science \\ and Technology University, Gopalganj 8100, Bangladesh \\ ${ }^{6}$ Institute Nuclear Science and Technology, Atomic Energy Research Establishment, Gonokbari, Savar, \\ Dhaka, Bangladesh \\ ${ }^{7}$ Neuroscience Department, Memorial University Newfoundland, Canada
}

\begin{abstract}
Article history:
Received: 20 September 2020

Received in revised form: 25

October 2020

Accepted: 17 December 2020

Available Online: 21 March

2021
\end{abstract}

Keywords:

Dry fish,

Chitosan,

Gamma radiation,

Fish preservation,

Microbial quality,

Blowfly

\section{DOI:}

https://doi.org/10.26656/fr.2017.5(2).520

\begin{abstract}
In Bangladesh, dry fishes are mostly produced by drying in an open environment under sunlight, and so the producers are forced to use insecticides and fungicides to prevent microbial and blowfly infestation. That is why dry fishes are often contaminated with residual insecticides and fungicides, which cause a severe threat to human health. In this experiment, gamma radiation treated chitosan solution was used while drying the fishes, and the effect was evaluated. Experimental results suggested that chitosan coating did not hinder the drying process but improved the quality of the produces. Chitosan coating was found as a repellant of blowflies as well. Besides, it also prevented microbial contamination. The nutritional value of the produced dry fishes was examined and found very satisfactory. Overall results suggested that the application of irradiated chitosan can be a very suitable and cost-effective way to produce safe and healthy dry fishes.
\end{abstract}

\section{Introduction}

In the sense of food concern, food security exists when all people from all classes have the basic and safe food they need. In Bangladesh, malnutrition remains all around, especially in the case of protein source food. In this regards, the high protein-containing dry fish can be a great source to meet the demand because the dry fishes are the predominant food bringing vital protein to people in rural areas of least developed countries (Graikoski, 1973). As Bangladesh is the sixth-largest fish producing county in aquaculture (Momtaz and Shameem, 2015), there is a huge opportunity for preserved fish in the country. But as a perishable nature and due to costly management system as fresh produce, in a developing country like Bangladesh, the drying method is considered as the least expensive method of fish preservation (Balachandran, 2001).

The drying method is the oldest food preservation technique and available in many chemical and processing industries. The eradication of moisture halts the rapid growth of microorganisms, causing decay and lessen much moisture mediated unexpected reactions (Kilic, 2009). About 15\% of fishes are cured for mass people consumption at the scarcity of fresh fishes in Bangladesh (Khan and Khan, 2001; Khan and Khan 2002). It is also a very favorite food item among Bangladeshi people and has a good market demand besides fish and other seafood products. Moreover, in the case of some marine fish species, e.g. loitta (Bombay duck), knife fish etc., people do not like to consume 
fresh fish, but they like to eat dry fish of these species (Siddique and Aktar, 2011). Moreover, dry fish has a storage life of several years and is a great source of protein, essential fatty acids, vitamins and a lot of minerals (Siddique and Aktar, 2011). So, it is consumed all over the world for its nutritional value, taste, and aroma.

During the rainy season, when humidity levels are high, and the sunlight is very low, sufficient drying cannot be achieved using traditional methods. Moreover, stored dried fish re-absorbs moisture in such conditions and becomes susceptible to bacteria, fungal or insect attack (Azam, 2002). In the Indonesian code of practice, for fresh and cured fish (Walker, 1984), it was stated that when the relative humidity was greater than $75 \%$, rehydration of dried fish happened if the product was not wrapped with polythene or another appropriate packaging. Wood (1981) stated the same opinion that in an atmosphere with a humidity greater than $60 \%$, the dry fish tended to pick up moisture, with a consequent risk of spoilage (Khan and Khan, 2001). For these reasons, dry fish farmers often use insecticides for protecting raw fish from insect attack, which is a serious health concern (Samad et al., 2009). Besides, blowfly infestation in sundrying fish is a major economic problem in many developing countries of Asia, Africa and the Pacific (Wall et al., 2001). Under warm and humid conditions, sun-drying fish can rapidly become infested by blowfly larvae (Kordyl, 1976). The infestation begins when adult females are attracted to the fish and lay eggs, particularly in the mouth and gills. The larvae feed initially in the body cavity, gills and eye sockets (Walker and Wood, 1986). On maturity, the larvae usually leave the fish and burrow into the soil beneath to pupate. The amount of damage caused by blowfly larvae depends largely on the speed of drying, the size of the fish, and whether the fish is salted or not (Walker and Wood, 1986). However, in extreme cases, larvae destroy all of the soft tissues, leaving only the skin, scales and bones (Walker and Donegan, 1984; Walker and Wood, 1986).

Fishers use a mixture of organochlorine insecticides to protect dry fish from infestation (Bhuiyan et al., 2008). Some analyses in Bangladesh showed alarming pollutants in fish like DDT and heptachlor (Bhuiyan et al., 2009; Chowdhury et al., 2010). In Kuakata (a fish processing zone in Bangladesh), a high level of DDT powder (locally known as white powder) is used, although Bangladesh banned the 'dirty dozen' in 1997 (Bhuiyan et al., 2009; Chowdhury et al., 2010). DDT is classified as "moderately toxic" by the US National Toxicological Program and "moderately hazardous" by $\mathrm{WHO}$ and a B2 probable human carcinogen (Bhuiyan et al., 2009; World Health Organization, 2010).

A natural bio-polymer, chitosan, can act as a chelating agent that chelate some metal ions needed by a bacterial enzyme belonging to cationized amines (Goy et al., 2009). It is known that cation $-\mathrm{NH}^{3+}$ can interrupt metabolism by interaction with other negative ions present at the bacterial cell wall, which causes internal osmotic imbalances and inhibits the growth of microorganisms (Hadwiger et al., 1986; Goy et al., 2009). Furthermore, some funguses are capable of producing carcinogenic ochratoxin $\mathrm{A}$ and aflatoxin, which may be inhibited by chitosan thorough chitosaninduced enhanced chitinase activity in host tissues (Goy et al., 2009; Sirmats, 2009; Matan, 2012). Besides, different treatments can further boost the effectiveness of chitosan. Gamma radiation leads to chain scission of chitosan molecules and produces oligomers with even better antimicrobial activity (Ibrahim et al., 2014). In this experiment, $40 \mathrm{kGy}$ gamma radiation dose was used to modify chitosan solution for better activity, optimized in our earlier experiments (Ibrahim et al., 2014).

Our present study evaluated the dry fish (Mola fish) preparation by dipping the fish in formulated chitosan solution and then allowed drying under sunlight. We have also observed the anti-microbiological effect of formulated chitosan as well as the efficacy of blowfly eradication.

\section{Material and methods}

\subsection{Materials}

Fresh Mola fish (Amblypharyngodon mola) were bought from the local market of Savar, Dhaka, Bangladesh. Fish were taken into a hermetically sealed container and brought into the laboratory for further experiment. Chitosan was extracted from the prawn shell in the Institute of Radiation of Polymer Technology (IRPT), Bangladesh Atomic Energy Commission laboratory by the standard chemical procedure (Rashid et al., 2012). The prepared chitosan was food grade, and the degree of deacetylation was $80-85 \%$. All other chemicals were lab grade and purchased from a local chemical supplier.

\subsection{Preparation of irradiated chitosan}

Chitosan solution $(2 \% \mathrm{w} / \mathrm{v})$ was prepared using $2 \%$ acetic acid. The prepared solution was then irradiated by Co-60 gamma irradiator at $40 \mathrm{kGy}$ with a dose rate of $6.93 \mathrm{kGy} / \mathrm{hour}$.

\subsection{Dry fish preparation}

Mola fishes were washed with distilled water and 
then treated with different concentrations of chitosan solution $(2000,3000,4000$ and $5000 \mathrm{ppm})$. Both treated and untreated (control) fishes were divided into two groups and were kept for room temperature drying (indoor) and sunlight drying (outdoor) in the IRPT campus, Savar, Dhaka, Bangladesh. Samples kept under sunlight took three days for drying, whereas indoor samples took five days. It was reported that fish samples dipped in $2 \%$ chitosan solution $(20,000 \mathrm{ppm})$ was safe for human consumption (Fan et al., 2009). However, in our experiment, we capped our treatment concentration at $5000 \mathrm{ppm}$ to make sure the treatment is safer.

\subsection{Microbiological analysis}

Microbiological analysis was conducted by means of total bacterial count and total fungal count. $1 \mathrm{~g}$ of dry fish sample was ground by a sterilized grinder and vortexed in distilled water to make $10 \mathrm{~mL}$ dry fish powder suspension. This suspension was further used to estimate the microbiological load. Plate count agar media (Oxoid, UK) was used for the total bacterial count, and potato dextrose agar media (Oxoid, UK) was used for the fungal count. The pour plate technique was used for both of the tests.

\subsection{Biochemical analysis}

The quality of samples was investigated by estimating protein, fat and moisture content according to the standard procedure of the Association of Official Analytical Chemists (AOAC).

\subsection{Blowfly infestation study}

This study is done by observing the number of blowflies attracted to the samples. The blowfly counting was started after three hours of chitosan treatment. Each day, three readings were taken at 2 hours of intervals. The total weight of the samples per experimental group was $500 \mathrm{~g}$, and the fishes were kept horizontally aligned.

\subsection{Statistical analysis}

Statistical analysis was conducted by SPSS software by means of standard deviation and one-way ANOVA.

\section{Results and discussion}

\subsection{Microbiology of dried fish}

Microbial activity is the main factor limiting the shelf life of fresh fish (Olafsdottir et al., 1997). In this experiment, the chitosan solution was used to inhibit microbial growth in the fish. Chitosan solutions were found to have a significant effect on controlling microbial growth at both room temperature and sunlight drying conditions. Bacterial counts were measured in
5000, 40003000 and $2000 \mathrm{ppm}$ chitosan treated samples and untreated sample as 4.0, 4.63, 5.11, 4.98 and 5.33 $\log _{10} \mathrm{CFU} / \mathrm{g}$, respectively (Figure 1) in sunlight drying condition. These results suggested about 13 times higher bacterial growth in the untreated sample compared with the $5000 \mathrm{ppm}$ chitosan treated sample. Similar results were found for the samples dried at room temperature (Figure 1); all chitosan treated samples got better results than untreated samples. The best outcome (4.47 $\log _{10} \mathrm{CFU} / \mathrm{g}$ ) was achieved for $5000 \mathrm{ppm}$ irradiated chitosan treatment. It was reported that cationized amines of chitosan chelated negatively charged potassium ions and other proteinaceous constituents of the microbial cell wall, making them locally detached from the cell membrane. This chelation also enabled the passing through murein and plasma membrane. Thus, chitosan bounds with microbial DNA and modulated transcriptional and translational mechanism (Goy et al., 2009; Alishahi, 2012). Moreover, chitosan acted as a water chelating agent in dry fish surface and microbial cell wall, which led to the blocking of active enzyme groups and toxin biosynthesis (Alishahi, 2012). All of these mechanisms eventually led to microbial growth retardation on the dry fish surface.

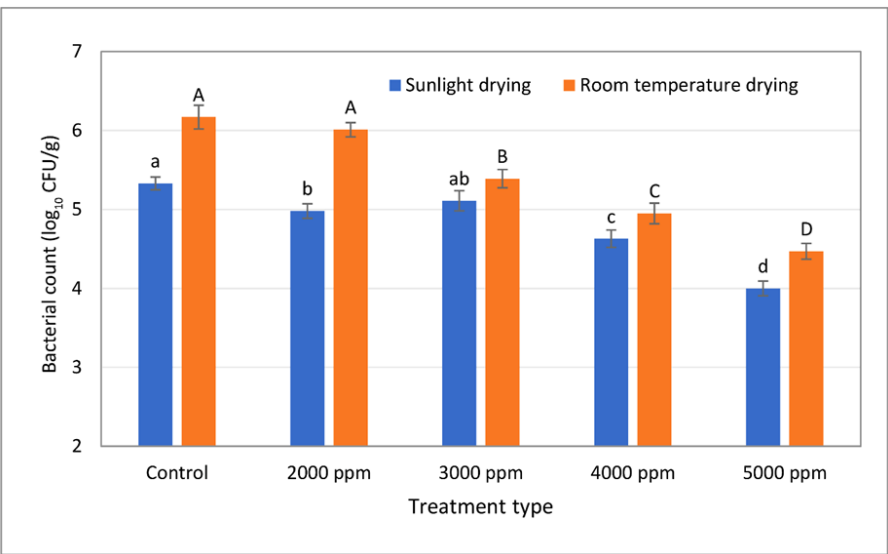

Figure 1. Bacterial count of the prepared dry fishes. Bars with different letters above are significantly different $(\mathrm{P}<0.05)$.

According to Prasad et al. (1994), salt-treated dry fishes contained Valamugil speigleri pathogen of 7.38 $\log _{10} \mathrm{CFU} / \mathrm{g}$, which is about double of total bacterial count found for chitosan treated dry Mola fish. According to Jay et al. (2008), the minimal reported growth restriction temperature for foodborne microbial species was $-5^{\circ} \mathrm{C}$, whereas we found significant bacterial growth retardation at room temperature due to chitosan treatment.

Auspicious results were also obtained in the case of fungal inhibition (Figure 2). Fungal growth was found about nil in the case of $3000 \mathrm{ppm}$ and higher doses of chitosan treatment under sunlight drying, whereas 5000 chitosan solution led to nil fungal growth for sample dried at room temperature. On the other hand, untreated 
dry fish samples showed fungal growth of $3.47 \mathrm{CFU} / \mathrm{g}$ and $4.24 \mathrm{CFU} / \mathrm{g}$ for sunlight drying and room temperature drying, respectively. Kilic (2009) and Patterson and Ranjitha (2009) found coldly dried $\left(20^{\circ} \mathrm{C}\right)$ rainbow trout fish contained 2.5-3.4 $\log _{10} \mathrm{CFU} / \mathrm{g}$, and the commercial sun-dried sample contained 1.3 $\log _{10} \mathrm{CFU} / \mathrm{g}$ total fungus count. So, the experimental results suggested that the 4000 ppm chitosan solution was sufficient to maintain the quality of the dry fish by keeping the fungal count below the same for conventional cool-drying samples as well as commercial sun-drying samples.

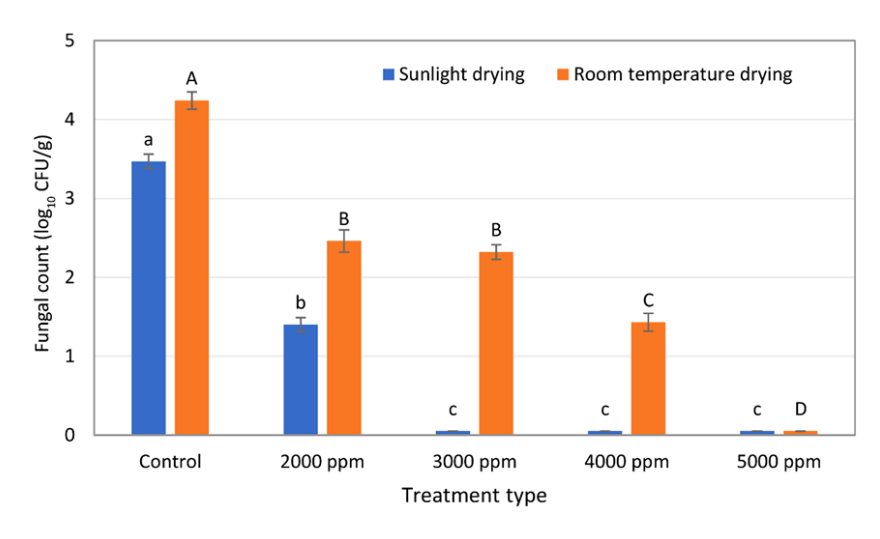

Figure 2. Fungal count of the prepared dry fishes. Bars with different letters above are significantly different $(\mathrm{P}<0.05)$.

On the other hand, dry fish samples treated with only acetic acid had no supplementary effect on the antimicrobial activity, suggesting that the antimicrobial effect was from the chitosan itself, not the solvent (acetic acid). Acetic acid-treated samples showed similar microbial counts as untreated samples in sunlight drying (bacterial count $5.24 \mathrm{CFU} / \mathrm{g}$, fungal count $4.20 \mathrm{CFU} / \mathrm{g}$ ). Zivanovic et al. (2004) also found similar results; lower concentration acetic had no antimicrobial properties, and microorganism was found to grow easily on the low concentration acetic acid-treated samples.

\subsection{Biochemical analysis}

The biochemical parameters like proteins, fat and moisture content of dry fish samples were estimated and are presented in Table 1. No significant difference was found between the nutritional values of the treated and untreated samples. However, overall sun-dried samples showed lower moisture content, and higher protein contents than room temperature dried samples. The untreated sample showed higher values of protein content which might occur due to the conversion of fish fat and other nutrients to microbiological biomass (bacteria and fungus), which is generally rich in protein. This trend is lower for chitosan treated samples, because the chitosan coating prevented bacterial and fungus attack into fish flesh. Additionally, the hydroxy group of chitin is replaced with the amino $\left(\mathrm{NH}_{2}\right)$ group in chitosan, which acted as a preservative agent (Augustini and Sedjati, 2007).

Therefore, in the untreated sample, the flavor, color and vitamin degradation occurred, and maybe the loss of essential amino acids also happened. In the case of chitosan treated samples, chitosan coating reduced oxygen penetration into the fish flesh and thus prevented aroma loss and solute transport out (Alishahi and Aïder, 2012). Ojagh et al. (2010) established that chitosan coatings extended the shelf life of refrigerated rainbow trout. Flowra et al. (2012) studied commercial five dried fish species. It reflected $44.08 \%$ to $65.65 \%$ protein content for different dried fish commercially available in Bangladesh (Bogard et al., 2015). 17\% and 8\% protein contents were observed in experimental and commercial dried Finfish chronologically (Patterson and Ranjitha, 2009). In our experiment, the protein content of chitosan treated all samples ranged from $56.8 \%$ to $62.6 \%$, which clarified its commercial and nutritional acceptances. Moisture percentage of commercial dry fishes were reported between 18-25\% (Flowra et al., 2012). In contrast, our samples showed $7.15 \%$ to $14.89 \%$ moisture content for sun-dried and room temperature dried samples, respectively, indicating the excellent quality of drying. However, it was found that all chitosan coating samples had a little higher moisture content compared to the untreated control samples. But the differences in the moisture content values were considerably low (Table 1). As the moisture content of standard commercial dry fish is $18-25 \%$, and any value less than this value indicates a higher quality of dry fish (Flowra et al., 2012), both treated and untreated samples had better quality compared to the commercial standard.

\subsection{Pest (Lucilia cuprina) infestation studies}

This study was undertaken to observe the presence

Table 1. Moisture, protein and fat content of untreated and treated Mola fish

\begin{tabular}{|c|c|c|c|c|c|c|}
\hline \multirow[b]{2}{*}{ Sample } & \multicolumn{2}{|c|}{ Moisture (\%) } & \multicolumn{2}{|c|}{ Protein $(\%)$} & \multicolumn{2}{|r|}{ Fat $(\%)$} \\
\hline & Sun drying & $\begin{array}{l}\text { Room temperature } \\
\text { drying }\end{array}$ & Sun drying & $\begin{array}{l}\text { Room temperature } \\
\text { drying }\end{array}$ & Sun drying & $\begin{array}{c}\text { Room temperature } \\
\text { drying }\end{array}$ \\
\hline Control (Untreated) & 7.15 & 10.46 & 64.12 & 62.60 & 21.40 & 19.90 \\
\hline $2000 \mathrm{ppm}$ & 8.15 & 12.73 & 62.60 & 59.50 & 25.20 & 22.30 \\
\hline $3000 \mathrm{ppm}$ & 8.32 & 13.20 & 62.47 & 58.20 & 25.50 & 23.60 \\
\hline $4000 \mathrm{ppm}$ & 8.28 & 13.55 & 61.42 & 58.70 & 25.40 & 23.80 \\
\hline $5000 \mathrm{ppm}$ & 8.68 & 14.89 & 61.72 & 56.80 & 25.60 & 23.40 \\
\hline
\end{tabular}


of blowfly in the fish samples (500 g). It was found that the blowflies attracted by the fish samples were reduced with the sunlight intensity. The blowfly infestation was also reduced with the degree of drying of the fish samples. On the other hand, the chitosan treated sample showed significant low blowfly infestation compared to the untreated control samples at both room temperature (simulation of cloudy day drying) and sunlight drying. In the case of sun-dried untreated control samples, the maximum fly infestation was found 19 at Day 2, 10.00 am. Whereas chitosan treated sample showed only two fly infestation at the same time for 5000 ppm treatment. Similar results were also found for the room temperature dried samples. The maximum fly infestation was 30 for the untreated control on Day 2, 2.00 pm. 3000 ppm chitosan treated sample was affected by only eight flies in the same period (Table 2, Figure 3). It was also found that the blowflies laid significantly less egg on the chitosan treated samples.

A second trial was conducted to evaluate whether the pest repellent effect was due to the chitosan coating or the odor of acetic acid. The trial confirmed that blowflies were attracted to not only untreated fish but also to acetic acid-treated fish samples (Table 3). Becher et al. (2010) also reported that the flies were strongly attracted the odor of acetic acid as the flies had an odor-mediated behavior to find out their feed.
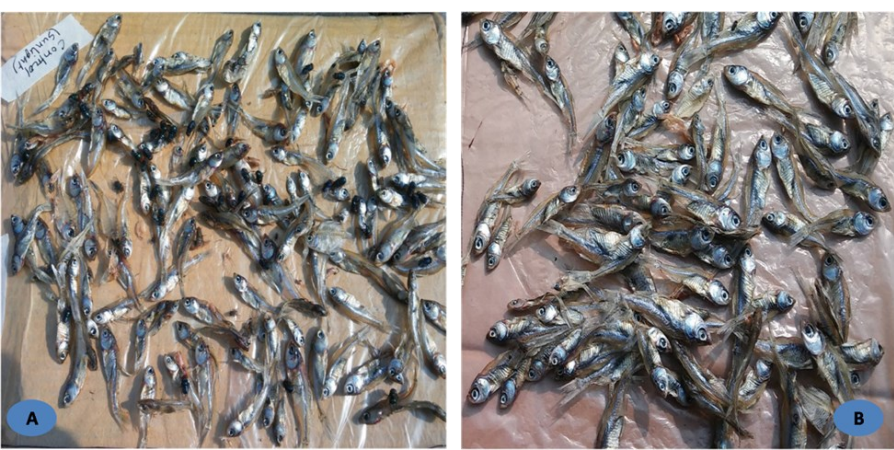

Figure 3. Blowfly infestation on dry fish samples; A (Control), B (5000 ppm chitosan treated).

It was also found that the blowflies ate the fish flesh that led to hallow structure formation in the fish sample (Figure 4). The experiment showed that blowfly easily penetrated, laid eggs in the untreated fish samples. The hatched larvae infected the fish samples and ate the soft

Table 2. Blowfly infestation on different dry fish samples

\begin{tabular}{|c|c|c|c|c|c|c|c|c|c|c|}
\hline & \multicolumn{9}{|c|}{ Blowfly count } \\
\hline & & \multicolumn{3}{|c|}{ Day 01} & \multicolumn{3}{|c|}{ Day 02} & \multicolumn{3}{|c|}{ Day 03} \\
\hline & & $10.00 \mathrm{am}$ & $12.00 \mathrm{pm}$ & $2.00 \mathrm{pm}$ & $10.00 \mathrm{am}$ & $12.00 \mathrm{pm}$ & $2.00 \mathrm{pm}$ & $10.00 \mathrm{am}$ & $12.00 \mathrm{pm}$ & $2.00 \mathrm{pm}$ \\
\hline \multirow{5}{*}{$\begin{array}{l}\text { Sun-dried } \\
\text { sample }\end{array}$} & Control & 4 & 8 & 6 & 19 & 14 & 12 & 7 & 0 & 0 \\
\hline & $2000 \mathrm{ppm}$ & 2 & 1 & 2 & 9 & 5 & 2 & 1 & 0 & 0 \\
\hline & $3000 \mathrm{ppm}$ & 2 & 0 & 1 & 8 & 3 & 7 & 2 & 0 & 0 \\
\hline & $4000 \mathrm{ppm}$ & 2 & 1 & 1 & 5 & 4 & 1 & 1 & 0 & 0 \\
\hline & $5000 \mathrm{ppm}$ & 2 & 1 & 0 & 2 & 2 & 0 & 0 & 0 & 0 \\
\hline \multirow{5}{*}{$\begin{array}{c}\text { Room } \\
\text { temperature } \\
\text { dried sample }\end{array}$} & Control & 3 & 6 & 10 & 26 & 31 & 30 & 29 & 21 & 20 \\
\hline & $2000 \mathrm{ppm}$ & 2 & 2 & 4 & 7 & 8 & 10 & 11 & 8 & 5 \\
\hline & $3000 \mathrm{ppm}$ & 2 & 3 & 2 & 5 & 5 & 8 & 4 & 4 & 2 \\
\hline & $4000 \mathrm{ppm}$ & 1 & 2 & 3 & 5 & 4 & 6 & 3 & 3 & 2 \\
\hline & $5000 \mathrm{ppm}$ & 1 & 1 & 2 & 4 & 3 & 7 & 3 & 4 & 2 \\
\hline
\end{tabular}

Table 3. Blowflies count of control, solvent treated (acetic acid) and $3000 \mathrm{ppm}$ chitosan treated fish samples during drying under sunlight

\begin{tabular}{ccccc}
\hline Day & Time & $\begin{array}{c}\text { Number of blowflies on } \\
\text { untreated dry fishes }\end{array}$ & $\begin{array}{c}\text { Number of blowflies on acetic } \\
\text { acid treated dry fishes }\end{array}$ & $\begin{array}{c}\text { Number of blowflies on } \\
\text { chitosan treated dry fishes }\end{array}$ \\
\hline & After one hour & 1 & 1 & 0 \\
& After two hours & 1 & 1 & 0 \\
$1^{\text {st }}$ day & After three hours & 1 & 1 & 1 \\
& After four hours & 2 & 2 & 0 \\
After five hours & 2 & 2 & 1 \\
\hline After one hour & 13 & 10 & 1 \\
$2^{\text {nd }}$ day & After two hours & 15 & 11 & 2 \\
After three hours & 13 & 12 & 2 \\
After four hours & 9 & 7 & 1 \\
\hline After five hours & 6 & 6 & 1 \\
After one hour & 14 & 12 & 1 \\
After two hours & 15 & 16 & 1 \\
After three hours & 9 & 11 & 0 \\
After four hours & 10 & 9 & 1 \\
\hline
\end{tabular}


tissues. In comparison, no hallow structure was found for the chitosan treated fish samples. Some researchers claimed that, nevertheless, using salt in dry fish processing, blowfly could easily pierce all of the soft tissue except only the skin, scales and bones (Walker and Donegan, 1984; Walker and Wood, 1986). However, our current investigation showed that no damage occurred to the soft tissues of chitosan treated dried fish.

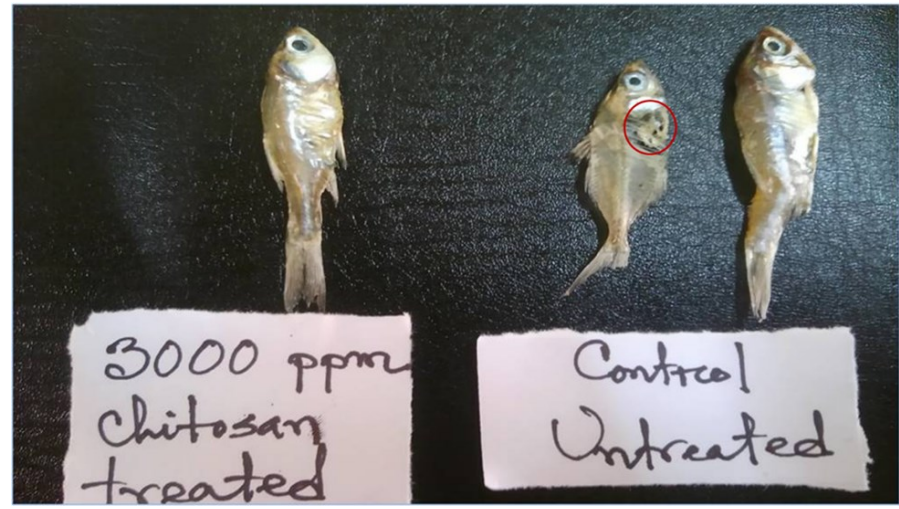

Figure 4. Soft tissues of the fish samples are eaten by blowflies and their larvae (in the circled area)

It can be assumed that the chitosan coating acted as a barrier for gas permeability and thus led to decreased smell emission from the fish samples. Moreover, it was found that chitosan solution had significant antibacterial and antifungal activity from the antimicrobial studies. So, the chitosan treated fishes had reduced flesh putrefaction and thus emitted less smell to attract blowflies. The combined effect of these two mechanisms ultimately led to the blowfly repellant characteristics of chitosan treatment.

\section{Conclusion}

The major challenges of producing dry fish are the blowfly attack and microbial degradation of the fish, especially when sunlight is absent for several days. In this experiment, we found the irradiated chitosan had a significant role in overcoming the challenges. Chitosan treatment was found to control both the blowfly infestation and microbial attack. Among the treatments 5000 ppm, chitosan solution showed the best results. However, the results for the 3000 ppm chitosan solution were also quite promising. Chitosan treatment did not show any effect on the drying time of the fish samples or the nutritional values of the dry fish. So, irradiated chitosan treatment before fish drying can be a very effective technique to produce healthy dry fishes without losing their quality and quantity. This practice will also discourage dry fish producers from using harmful chemicals and pesticides as they can now get rid of blowfly and microbial attack using human healthfriendly chitosan treatment. Thus the research can play a critical role to ensure food safety and security worldwide.

\section{Acknowledgement}

The authors are grateful to the staffs of Institute of Radiation and Polymer Technology, Atomic Energy Research Establishment, Savar, Dhaka, Bangladesh, especially Md. Sumon Hossain for his support in sample collection and sample handling.

\section{References}

Alishahi, A. (2012). Chitosan: A Bioactive Polysaccharide in Marine-Based Foods. In Karunaratne, D.N (Eds). The Complex World of Polysaccharides, p. 409-428. Croatia: InTech. https:// doi.org/10.5772/48199

Alishahi, A. and Aïder, M. (2012). Applications of chitosan in the seafood industry and aquaculture: a review. Food Bioprocess Technology, 5(3), 817-830. https://doi.org/10.1007/s11947-011-0664-x

Augustini, T. and Sedjati, S. (2007). The effect of chitosan concentration and storage time on the quality of salted-dried Anchovy (Stolephorus heterolobus). Journal of Coastal Development, 10 (2), 63-71.

Azam, K. (2002). Fishermen Community of Kuakata, Bangladesh: Fisheries Activities and Quality of Dried Fish, SUFER Project (DFID-UGC), p. 2, Bangladesh: Khulna University.

Balachandran, K. (2001). Post-harvest technology of fish and fish products. Delhi, India: Daya Books.

Becher, P.G., Bengtsson, M., Hansson, B.S. and Witzgall, P. (2010). Flying the fly: long-range flight behavior of Drosophila melanogaster to attractive odors. Journal of Chemical Ecology, 36(6), 599-607. https://doi.org/10.1007/s10886-010-9794-2

Bhuiyan, M.N.H., Bhuiyan, H.R., Ahmed, K., Dawlatana, M., Haque, K.F., Rahim, M. and Bhuiyan, M. N.I. (2009). Organochlorine insecticides (DDT and heptachlor) in dry fish: Traditional washing and cooking effect on dietary intake. Bangladesh Journal of Pharmacology, 4(1), 46-50. https://doi.org/10.3329/bjp.v4i1.1051

Bhuiyan, M.N.H., Bhuiyan, H.R., Rahim, M., Ahmed, K., Haque, K.F., Hassan, M.T. and Bhuiyan, M.N.I. (2008). Screening of organochlorine insecticides (DDT and heptachlor) in dry fish available in Bangladesh. Bangladesh Journal of Pharmacology, 3(2), 114-120. https://doi.org/10.3329/bjp.v3i2.997

Bogard, J.R., Thilsted, S.H., Marks, G.C., Wahab, M.A., Hossain, M.A., Jakobsen, J. and Stangoulis, J. (2015). Nutrient composition of important fish 
species in Bangladesh and potential contribution to recommended nutrient intakes. Journal of Food Composition Analysis, 42, 120-133. https:// doi.org/10.1016/j.jfca.2015.03.002

Chowdhury, M., Amin-ud-Din, M., Malek, M. and Zaman, M. (2010). DDT residue and its metabolites in dried fishes of Dhaka city markets. Soil Environment, 29(2), 117-121.

Fan, W., Sun, J., Chen, Y., Qiu, J., Zhang, Y. and Chi, Y., (2009). Effects of chitosan coating on quality and shelf life of silver carp during frozen storage. Food Chemistry, 115(1), 66-70. https://doi.org/10.1016/ j.foodchem.2008.11.060

Flowra, F.A., Tumpa, A.S. and Islam, M.T. (2012). Biochemical analysis of five dried fish species of Bangladesh. University Journal of Zoology, Rajshahi University, 31, 9-11. https://doi.org/10.3329/ ujzru.v31i0.15373

Goy, R.C., Britto, D.D. and Assis, O.B. (2009). A review of the antimicrobial activity of chitosan. Polimeros, 19(3), 241-247. https://doi.org/10.1590/S010414282009000300013

Graikoski, J.T. (1973). Microbiology of cured and fermented fish. In Chichester, C.O. and Graham, H.D. (Eds). Microbial safety of fishery products, p. 102-104. London: Academic Press. https:// doi.org/10.1016/B978-0-12-172740-6.50014-6

Hadwiger, L., Kendra, D., Fristensky, B. and Wagoner, W. (1986). Chitosan both activates genes in plants and inhibits RNA synthesis in fungi. In Muzzarelli, R., Jeuniaux, C. and Gooday G.W. (Eds). Chitin in Nature and Technology. Boston, USA: Springer. https://doi.org/10.1007/978-1-4613-2167-5_28

Ibrahim, S.M., Nahar, S., Islam, J.M., Islam, M., Hoque, M., Huque, R. and Khan, M.A. (2014). Effect of low molecular weight chitosan coating on physicochemical properties and shelf life extension of pineapple (Ananas sativus). Journal of Forest Products and Industries, 3(3), 161-166.

Jay, J.M., Loessner, M.J. and Golden, D.A. (2008). Modern food microbiology. 7th ed. USA: Springer Science and Business Media.

Khan, M.A.A. and Khan, Y.S.A. (2001). Insect infestation and preventive measures in dry fish storage of Chittagong, Bangladesh. International Journal of Biological Sciences, 1(10), 963-965. https://doi.org/10.3923/jbs.2001.963.965

Khan, M.A.A. and Khan, Y.S.A. (2002). Study on the abundance and infestation of blowfly during drying of fish in the coastal area of Bangladesh. Journal of Biological Sciences, 1(7), 499-501. https:// doi.org/10.3923/jbs.2002.499.501
Kilic, A. (2009). Low temperature and high velocity (LTHV) application in drying: Characteristics and effects on the fish quality. Journal of Food Engineering, 91(1), 173-182. https:// doi.org/10.1016/j.jfoodeng.2008.08.023

Kordyl, E. (1976). Some protective measures against insect infestation of dried fish in Africa presented at the Proceedings of the Conference on Handling, Processing and Marketing of Tropical Products Institute, 1976, London, UK.

Matan, N. (2012). Antimicrobial activity of edible film incorporated with essential oils to preserve dried fish (Decapterus maruadsi). International Food Research Journal, 19(4), 1733 - 1738.

Momtaz, S. and Shameem, M. (2015). Experiencing climate change in Bangladesh: Vulnerability and adaptation in coastal regions. London: Academic Press.

Ojagh, S.M., Rezaei, M., Razavi, S.H. and Hosseini, S.M.H. (2010). Effect of chitosan coatings enriched with cinnamon oil on the quality of refrigerated rainbow trout. Food Chemistry, 120(1), 193-198. https://doi.org/10.1016/j.foodchem.2009.10.006

Olafsdottir, G., Martinsdóttir, E., Oehlenschläger, J., Dalgaard, P., Jensen, B., Undeland, I., Mackie, I. M., Henehan, G., Nielsen, J. and Nilsen, H. (1997). Methods to evaluate fish freshness in research and industry. Trends in Food Science Technology, 8(8), 258-265. https://doi.org/10.1016/S0924-2244(97) 01049-2

Patterson, J. and Ranjitha, G. (2009). Qualities of commercially and experimentally sun dried fin fish, Scomberoides tol. African Journal of Food Science, 3(10), 299-302.

Prasad, M., Rao, C. and Gupta, S. (1994). Chemical and microbiological quality of dry fish from Kakinada. Fisheries Technology, 31(1), 75-78.

Rashid, T.U., Rahman, M.M., Kabir, S., Shamsuddin, S.M. and Khan, M.A. (2012). A new approach for the preparation of chitosan from $\gamma$-irradiation of prawn shell: effects of radiation on the characteristics of chitosan. Polymer International, 61 (8), 1302-1308. https://doi.org/10.1002/pi.4207

Samad, M., Galib, S. and Flowra, F. (2009). Fish drying in Chalan Beel areas. Bangladesh Journal of Scientific Industrial Research, 44(4), 461-466. https://doi.org/10.3329/bjsir.v44i4.4599

Siddique, M.A.M. and Aktar, M. (2011). Changes of nutritional value of three marine dry fishes (Johnius dussumieri, Harpodon nehereus and Lepturacanthus savala) during storage. Food Nutrition Sciences, 2, 1082-1087. https://doi.org/10.4236/fns.2011.210145 
Sirmats, E. (2009). Effect of molecular weight reduction by gamma irradiation on the antimicrobial activity of chitosan. South Carolina, USA: Clemson University, PhD Dissertation.

Walker, D. (1984). Report on a visit to Indonesia to present recommendations of the joint Humberside college. TDRI project to reduce post-harvest losses in cured marine cat fish. [Unpublished Report].

Walker, D. and Donegan, L. (1984). Spray application of insecticides to protect sundrying fish from blowfly infestation during the wet season in Malawi. International Pest Control, 26(5), 132-137.

Walker, D. and Wood, C. (1986). Non-insecticidal methods of reducing losses caused by infestation of blow-flies (Diptera) during fish curing procedures. FAO Fisheries Report, FAO Accession No: XF8660199. Rome: FAO.

Wall, R., Howard, J. and Bindu, J. (2001). The seasonal abundance of blowflies infesting drying fish in south -west India. Journal of Applied Ecology, 38(2), 339348. https://doi.org/10.1046/j.13652664.2001.00588.x

World Health Organization (2010). The WHO Recommended Classification of Pesticides by Hazard and Guidelines to Classification 2009. Germany: World Health Organization.

Wood, C. (1981). The prevention of losses in cured fish (spoilage). FAO Fisheries Technical Papers, no. 219. Rome: FAO.

Zivanovic, S., Basurto, C., Chi, S., Davidson, P. and Weiss, J. (2004). Molecular weight of chitosan influences antimicrobial activity in oil-in-water emulsions. Journal of Food Protection, 67(5), 952959. https://doi.org/10.4315/0362-028X-67.5.952 